\title{
Consciousness of Dairy Farmers about Brucellosis
}

\author{
S. J. Jadav ${ }^{1 *}$ and S. K. Raval ${ }^{2}$ \\ ${ }^{1}$ Dairy Vigyan Kendra, SMC College of Dairy Science, Anand Agricultural University, \\ Anand-388110, Gujarat, India \\ ${ }^{2}$ Department of Veterinary Medicine, College of Veterinary Science and Animal Husbandry, \\ Anand, Anand Agricultural University, Anand-388110, Gujarat, India \\ *Corresponding author
}

\section{A B S T R A C T}

The study was an emphasis on consciousness of dairy farmers about brucellosis. Brucellosis is one of the zoonotic diseases. Zoonotic diseases mean diseases which are transmitted from animal to human or human to animal. Using the simple random sampling

\begin{tabular}{|l|}
\hline Key w or d s \\
Knowledge, Dairy \\
Farmers, \\
Brucellosis, \\
Zoonotic Disease \\
\hline Article Info \\
\hline $\begin{array}{l}\text { Accepted: } \\
\text { 15 August } 2019 \\
\text { Available Online: } \\
\text { 10 September } 2019\end{array}$ \\
\hline \hline
\end{tabular}
method, 120 respondents from 12 villages of 6 talukas in the operational area of Dairy Vigyan Kendra, Vejalpur (DVK) were selected. Overall knowledge level of brucellosis among dairy farmers was low. Knowledge of brucellosis was divided into six components; General information of brucellosis, transmission, symptoms of animal, symptoms of human, control and preventive aspects. An arrangement of the major components of knowledge level of dairy farmers about brucellosis as 'Control $\rightarrow$ Prevention $\rightarrow$ Transmission $\rightarrow$ Symptoms of animal $\rightarrow$ Symptoms of human $\rightarrow$ General information' ordered in decreasing trend. There were more than half of dairy farmers had knowledge about buffalo (59.17\%) \& cow (56.67\%) can be susceptible to brucellosis but very few in other species. No one dairy farmer had any knowledge about principle causative agent and vaccine name of brucellosis. Correlation ' $r$ ' computed between knowledge level of dairy farmers about brucellosis and experience in dairy farming (0.253), social participation (0.261), extension participation (0.471) and mass media exposure (0.375) were found to be significant at 0.01 level of significance. Majority of dairy farmers disagreed to sell susceptible or detected as brucellosis animals to neighbors $(98.33 \%)$ or relatives $(96.67 \%)$ or in the market $(93.33 \%)$. There was 45.00 per cent of respondents consumed milk regularly from their own animal. The majority of respondents $(65.83 \%)$ boiled milk regularly before it was consumed. Persons who directly or indirectly associated with different livestock animals should be provided training and information regarding brucellosis.

\section{Introduction}

Brucellosis is one of the grievous zoonotic diseases in the world. Zoonotic disease means that the diseases which are naturally transmitted from animal to human and vice- versa. Brucellosis is a zoonotic disease that affects humans, animals and wildlife. The principle cause of bovine brucellosis is Brucella abortus. In the $18^{\text {th }}$ century contagious abortion was observed and the agent involved in it known as Brucella 
abortus was discovered by Bang in 1897 in Denmark.Brucellosis of animal has affected adversely on animal production-productivity and human health. However, when the incidence of brucellosis is controlled in the animal reservoirs, there is a corresponding and significant decline in the incidence in humans (Seleemet al.,2010). The incidence of brucellosis in animals \& humans which directly or indirectly relates on animal husbandry practices, living standards, hygiene, the interaction between humans and animals, food customs, and animal and human population density. Brucellosis is a chronic infection which can result in abortion, infertility, delayed heat, interrupted lactation, decrease animal production in domestic animals. Brucellosis can be susceptible in species of animals vi., buffalo, sheep, goat, cat, dog, swine, poultry, camel, horse, yaks, wild animals and human also. Consumption of contaminated milk and milk products, undercooked meat such as spleen, liver are mainly responsible for human brucellosis. Further, contact with vaginal discharge, urine, faeces and blood of infected animals through broken skin and mucous membrane of conjunctiva and inhalation of the organism can cause the disease. The aim of the study was evaluate the dairy farmers' consciousness about brucellosis in the operational area of Dairy Vigyan Kendra, Vejalpur.

\section{Materials and Methods}

Between September, 2018 to December, 2018 an interview schedule survey was conducted among dairy farmers in the operational area of Dairy Vigyan Kendra, Vejalpur (DVK, Vejalpur).DVK, Vejalpur established by the Government of Gujarat on $19^{\text {th }}$ January 2013 at Vejalpur, under Anand Agricultural University, Anand to cater training need of the dairy farmers, to boost clean milk production and to increase animal productivity. The operational area of DVK is old Panchmahal district of Gujarat.Panchmahal district located between 20.300 to $23.300 \mathrm{~N}$ latitude and 73.150 to 74.000 E longitudes and at $217 \mathrm{~m}$ AMSL (above mean sea level). Panchmahal district is within the border of Dahod District to the east, Vadodara district to the south, Rajasthan state to the east and Kheda district to the west.

Total six talukas of the operational area of DVK was randomly selected for the study. Two villages were selected randomly from each taluka and 10 dairy farmers were randomly selected from each village, thus making the total sample of 120 dairy farmers. A standardized, well-structured pre-tested interview schedule was prepared in light of the objectives in consultation with veterinary public health and veterinary medicine experts. The data were collected through personal interview method.

\section{Limitation}

The study was based on the information collected from the respondents for only one year i.e. 2018

\section{Results and Discussion}

Data presented in table 1 revealed the complete profile of dairy farmers comprising of different personal and socio-economical characteristics. In the study area, the majority of respondents $(72.50 \%)$ were female. The majority of dairy farmers belonged to secondary education (32.50\%), 31.67 per cent farmers had experience up to 5 years. Regarding livestock composition, a high majority of dairy farmers $(84.17 \%)$ had buffalo animal followed by cow $(63.33 \%)$, goat $(22.50 \%)$, poultry $(6.67 \%)$ and horse $(0.83 \%)$. In the case of livestock herd size, Majority of dairy farmers $(44.17 \%)$ had medium livestock herd size. The respondents $(43.33 \%)$ fell in medium social participation, 
dairy farmers $(38.33 \%)$ fell in low extension participation, dairy farmers (48.33\%) belonged to low mass media exposure in the operational area of DVK.

It is seen in table 2 that very less per cent of respondents $(0.83 \%)$ had knowledge about zoonotic disease. The majority of dairy farmers did not have knowledge about zoonotic disease. They did not know the meaning of zoonotic. Only 6.67 per cent of dairy farmers knew that brucellosis is one of zoonotic disease. In similar result with 13.33 per cent of farmers of Anand district of Gujarat believed that brucellosis is a zoonotic disease (Thakkar, 2013). In Punjab, 46.0\% of livestock farmers were aware of zoonotic nature of brucellosis (Hundal et al., 2016). But in contrast (Díez \& Coelho 2013) reported that $74.7 \%$ farmer believed that brucellosis was a zoonotic disease. Only 4.17 per cent of respondents had knowledge that the cause of brucellosis is bacteria. There were 59.17 per cent of respondents had knowledge about buffalo can be susceptible to brucellosis followed by cow (56.67\%), sheep \& goat (25.83\%), dog \& cat $(15.83 \%)$ and horse \& camel $(6.67 \%)$. There was no one had knowledge about the causative agent of bovine brucellosis. The principle cause of bovine brucellosis is Brucella abortus bacteria. Only 5.00 per cent of respondents able to answer that bovine brucellosis were diagnosed with serological test at a laboratory. Only 0.83 per cent of respondents answered right on the question of bovine brucellosis as a curable disease. Conversely, 99.13 per cent of respondents believed that bovine brucellosis can be a cure. Over half of the respondents $(54.5 \%)$ believed that bovine brucellosis was a treatable infectious disease reported by Díez \& Coelho 2013. Bovine brucellosis could not a curable disease in bovine. Regarding the transmission of bovine brucellosis disease (Table 3), 38.33 per cent of dairy farmers believed that bovine brucellosis can be transmitted to both male \& female and female farmers only $(38.33 \%)$ followed by male farmers only (23.34\%). The farmers $(21.67 \%)$ believed that brucellosis of human can be transmitted to cattle. The majority of dairy farmers had not knowledge that bovine brucellosis can be transmitted from human to animal or animal to human. It is seen in table 3 that more than one-third $(35.83 \%)$ of the dairy farmers had knowledge that ingestion of contaminated milk is a transmission route for brucellosis. There was $87 \%$ of the participants indicated that the consumption of unpasteurized milk is associated with a high risk of infection (Imadidden et al., 2015).There was $30.00 \%$ farmers had knowledge that ingestion of food and water contaminated with discharges of aborted foetus or foetus membranes followed by $29.17,24.17,23.33,15.83,12.50,10.83,3.33$ and 3.33 of them with knowledge about ingestion of contaminated milk's products like cheese, ice cream and yoghurt, Uncooked infected animal's meat such as liver \& spleen, Bite of arthropods, Intact or abraded skin, inhalation, Contact of infected animal's vaginal discharge, Conjunctiva \& Congenital Infection, respectively.

When asked about the symptoms of animal suffering from bovine brucellosis (Table 4), majority of dairy farmers $(40.00 \%)$ had knowledge that it causes interrupted lactation followed by abortion in last trimester in animal (28.33\%), retention of placenta in animal (25.83\%), infertility (20.00\%), delay heat in animal (18.33\%), hygroma (15.83\%), epididymitis and orchitis in the male animal $(10.83 \%)$ and loose sexual desire and infertility in the bull (9.17\%).

The result was differed with (Imadidden et al., 2015) and reported that $76.4 \%$ of participants indicated that abortion is the most prominent clinical sign. A considerable proportion of participants also identified difficulties to 
become pregnant (61.3\%), weight loss $(59.5 \%)$, and drop in milk production (49\%).

Regarding symptoms of human who suffering from brucellosis was presented in table 5 and reported that 26.67 per cent of respondents indicated that anorexia is the most prominent clinical sign based on their knowledge. A considerable proportion of participants also identified to undulant fever \& headache $(25.83 \%)$, infertility in human $(20.00 \%)$, constipation (18.33\%), arthralgia \& insomnia $(17.50 \%)$, depression (15.83\%), sexual impotence (14.16\%) and arthritis, spondylitis, sacroiliitis, osteomyelitis, meningoencephalitis and endocarditis (1.67\%) caused by brucellosis in human.

The data presented in table 6 regarding practices of control of brucellosis disease, most of the farmers buried or burnt a dead calve carcass and remaining farmers $(9.17 \%)$ throw the carcass outside village or farm. Majority of dairy farmers $(87.50 \%)$ called the veterinarian for treatment of animals within 24 hours of onset of symptoms.

Almost half of the respondents $(49.17 \%)$ were not allowed to brucellosis diseased person to treat or handle their animal. 45.83 per cent of dairy farmers had not allowed an injured person to treat or handle the animals without protection.

Preventive aspects of brucellosis presented in table 7 indicated that majority of dairy farmers $(77.50 \%)$ had knowledge that regular disinfected of animal sheds followed by care should be taken while handling and disposing of foetus, placental membrane and uterine discharge $(65.00 \%)$, Proper boiling and pasteurization of milk \& its products (56.67\%), Using protective wears like apron, gloves, gumboots, masks, etc. (52.50\%), To avoid the consumption of uncooked/ undercooked meat(50.83\%), Tick control
(41.17\%), Vaccination (30.00\%), Control of animal movements (18.33\%). The farmers had very less knowledge regarding brucella testing in animals twice a year\& Strain-19 vaccine used to female calves (5.00\%), Strain-19 Brucella vaccine can be used to which age of animal ideally $(3.33 \%)$ and S-19 vaccine can use to male calves $(2.50 \%)$.

It means 97.50 per cent of dairy farmers believed that S-19 vaccine can be used to male calves. No one of dairy farmers had knowledge about the name vaccine of brucellosis.

Knowledge level of different category of dairy farmers about brucellosis presented in table 8 and revealed that 93.33 per cent of dairy farmers had low level of knowledge about general information of brucellosis disease like a causative agent, susceptible animals etc. followed by symptoms of human $(76.67 \%)$, symptoms of animals (71.67\%).There was 45.00 per cent and 39.17 per cent of dairy farmers had high and medium level of knowledge on control of brucellosis respectively.

The dairy farmer had low level knowledge regarding transmission route of disease (70.83\%). In favour of the result (Arif et al., 2017) reported that almost all farmers (97\%) were not aware of the modes of transmission of brucellosis.

Knowledge level of dairy farmers in major components about brucellosis presented in table 9 and revealed that an arrangement of major components of knowledge level of dairy farmers about brucellosis as 'Control $\rightarrow$ Prevention $\rightarrow$ Transmission $\rightarrow$ Symptoms of animal $\rightarrow$ Symptoms of human $\rightarrow$ General information' ordered in decreasing trend of dairy farmers' knowledge level about brucellosis in these major activities. 
Table.1Profile of dairy farmers

$(\mathrm{n}=120)$

\begin{tabular}{|c|c|c|}
\hline Sr. No. & Profile of dairy farmers & No. $(\%)$ of participants \\
\hline 1 & Sex & \\
\hline $\mathbf{i}$ & Male & $33(27.50)$ \\
\hline ii & Female & $87(72.50)$ \\
\hline 2 & Age & \\
\hline i & Young ( $\leq 30$ years) & $22(18.33)$ \\
\hline ii & Middle aged (31-50 Years) & $71(59.17)$ \\
\hline iii & Old $(>50$ Years $)$ & $27(22.50)$ \\
\hline 3 & Education & \\
\hline i & Illiterate & $28(23.33)$ \\
\hline ii & primary education & $30(25.00)$ \\
\hline iii & secondary education & $39(32.50)$ \\
\hline iv & higher secondary education & $14(11.67)$ \\
\hline $\mathbf{v}$ & Graduate and above & $9(7.50)$ \\
\hline 4 & Experience in dairy farming & \\
\hline $\mathbf{i}$ & up to 5 years & $38(31.67)$ \\
\hline ii & 6 to 10 years & $20(16.67)$ \\
\hline iii & 11 to 15 years & $11(9.17)$ \\
\hline iv & 16 to 20 years & $17(14.16)$ \\
\hline $\mathbf{v}$ & Above 20 years & $34(28.33)$ \\
\hline 5 & Caste & \\
\hline i & ST & $20(16.67)$ \\
\hline ii & $\mathrm{SC}$ & $12(10.00)$ \\
\hline iii & SEBC & $63(52.50)$ \\
\hline iv & GENERAL & $25(20.83)$ \\
\hline 6 & Family type & \\
\hline i & Nuclear family & $63(52.50)$ \\
\hline ii & Joint family & $57(47.50)$ \\
\hline 7 & Family size & \\
\hline i & Small family (Up to 5 members) & $55(45.84)$ \\
\hline ii & Medium family (From 6 to 8 members) & $37(30.83)$ \\
\hline iii & Large family (Above 8 members) & $28(23.33)$ \\
\hline 8 & Landholding & \\
\hline i & Landless farmers & $6(5.00)$ \\
\hline ii & Marginal farmer (Up to $1.00 \mathrm{ha}$ ) & $68(56.67)$ \\
\hline iii & Small farmer (1.01 to $2.00 \mathrm{ha})$ & $22(18.33)$ \\
\hline iv & Medium farmer (2.01 to $4.00 \mathrm{ha})$ & $21(17.50)$ \\
\hline $\mathbf{v}$ & Large farmer (Above $4.00 \mathrm{ha}$ ) & $3(2.50)$ \\
\hline 9 & Livestock Composition & \\
\hline i & Cow & $76(63.33)$ \\
\hline ii & Buffalo & $101(84.17)$ \\
\hline iii & Goat & $27(22.50)$ \\
\hline iv & Sheep & $0(0.00)$ \\
\hline $\mathbf{v}$ & Horse & $1(0.83)$ \\
\hline vi & Donkey & $0(0.00)$ \\
\hline
\end{tabular}




\begin{tabular}{|c|c|c|}
\hline vii & Poultry & $8(6.67)$ \\
\hline 10 & \multicolumn{2}{|l|}{ Livestock Herd Size } \\
\hline i & Small (M-1/2SD) & $44(36.67)$ \\
\hline ii & MediumIn between (Mean \pm 1/2S.D.) & $53(44.17)$ \\
\hline iii & Large $(\mathrm{M}+1 / 2 \mathrm{SD})$ & $23(19.16)$ \\
\hline iv & Mean & 6.01 \\
\hline $\mathbf{v}$ & SD & 5.49 \\
\hline 11 & \multicolumn{2}{|l|}{ Social participation } \\
\hline i & Low (M-1/2SD) & $45(37.50)$ \\
\hline ii & Medium In between (Mean \pm 1/2S.D.) & $52(43.33)$ \\
\hline \multirow[t]{3}{*}{ iii } & High $(\mathrm{M}+1 / 2 \mathrm{SD})$ & $23(19.17)$ \\
\hline & Mean & 1.025 \\
\hline & SD & 1.29 \\
\hline 12 & \multicolumn{2}{|l|}{ Extension participation } \\
\hline i & Low $(\mathrm{M}-1 / 2 \mathrm{SD})$ & $46(38.33)$ \\
\hline ii & Medium In between (Mean $\pm 1 / 2 \mathrm{SD}$ ) & $34(28.33)$ \\
\hline \multirow[t]{3}{*}{ iii } & High $(\mathrm{M}+1 / 2 \mathrm{SD})$ & $40(33.34)$ \\
\hline & Mean & 6.47 \\
\hline & SD & 4.34 \\
\hline 13 & \multicolumn{2}{|l|}{ Mass media exposure } \\
\hline i & Low (Mean - 1/2SD) & $58(48.33)$ \\
\hline ii & Medium In between (Mean $\pm 1 / 2 \mathrm{SD})$ & $27(22.50)$ \\
\hline \multirow[t]{3}{*}{ iii } & High $($ Mean $+1 / 2 \mathrm{SD})$ & $35(29.17)$ \\
\hline & Mean & 1.98 \\
\hline & S.D. & 1.93 \\
\hline
\end{tabular}

Table.2 Knowledge of dairy farmers about general information of brucellosis

\begin{tabular}{|l|l|l|l|}
\hline Sr.No & Statements & No. (\%) of participants \\
\hline $\mathbf{1}$ & & Zoonotic disease & $1(0.83)$ \\
\hline $\mathbf{2}$ & & Brucellosis as a zoonotic disease & $8(6.67)$ \\
\hline $\mathbf{3}$ & & As per your opinion, causes of brucellosis \\
\hline & a. & Virus & $1(0.83)$ \\
\hline & b. & Bacteria & $5(4.17)$ \\
\hline & c. & Fungi & $0(0.00)$ \\
\hline & d. & Parasite & $0(0.00)$ \\
\hline $\mathbf{4}$ & & Susceptible animals that can have brucellosis & \\
\hline & a. & Cow & $68(56.67)$ \\
\hline & b. & Buffalo & $71(59.17)$ \\
\hline & c. & Dog \& Cat & $19(15.83)$ \\
\hline & d. & Sheep \& Goat & $31(25.83)$ \\
\hline & e. & Horse & $8(6.67)$ \\
\hline & f. & Camel & $8(6.67)$ \\
\hline $\mathbf{5}$ & & Causative agent of bovine brucellosis & $0(0.00)$ \\
\hline $\mathbf{6}$ & & Bovine brucellosis diagnosis by serological test & $6(5.00)$ \\
\hline $\mathbf{7}$ & & Bovine brucellosis as a curable disease & $1(0.83)$ \\
\hline
\end{tabular}


Table.3 Knowledge of dairy farmers about transmission of brucellosis

$(n=120)$

\begin{tabular}{|l|l|l|}
\hline Sr. No & Statements & No. (\%) of participants \\
\hline $\mathbf{1}$ & Bovine brucellosis transmitted to male farmers only. & $28(23.34)$ \\
\hline $\mathbf{2}$ & Bovine brucellosis transmitted to female farmers only. & $46(38.33)$ \\
\hline $\mathbf{3}$ & Bovine brucellosis transmitted to both male \& female. & $46(38.33)$ \\
\hline $\mathbf{4}$ & Brucellosis of dairy farmers transmitted to cattle. & $26(21.67)$ \\
\hline $\mathbf{5}$ & Brucellosis of animals can transmit to man and vice versa through: \\
\hline $\mathbf{A}$ & $\begin{array}{l}\text { Ingestion of food and water contaminated with discharges of aborted } \\
\text { foetus or foetus membranes. }\end{array}$ & $36(30.00)$ \\
\hline $\mathbf{B}$ & Ingestion of contaminated milk & $43(35.83)$ \\
\hline $\mathbf{C}$ & $\begin{array}{l}\text { Ingestion of contaminated milk's products like dahi, cheese, ice cream } \\
\text { etc. }\end{array}$ & $35(29.17)$ \\
\hline $\mathbf{D}$ & Uncooked infected animal's meat such as liver \& spleen. & $29(24.17)$ \\
\hline $\mathbf{E}$ & Inhalation route & $15(12.50)$ \\
\hline $\mathbf{F}$ & Contact of infected animal's vaginal discharge & $13(10.83)$ \\
\hline $\mathbf{G}$ & Bite of arthropods & $28(23.33)$ \\
\hline $\mathbf{H}$ & Intact or abraded skin & $19(15.83)$ \\
\hline $\mathbf{I}$ & Conjunctiva & $4(3.33)$ \\
\hline $\mathbf{J}$ & Congenital Infection & $4(3.33)$ \\
\hline
\end{tabular}

Table.4 Knowledge of dairy farmers about symptoms of animal (suffering from brucellosis)

\begin{tabular}{|l|l|l|}
\hline Sr. No & Statements & No. $(\%)$ of participants \\
\hline $\mathbf{1}$ & Abortion in last trimester in animal & $34(28.33)$ \\
\hline $\mathbf{2}$ & Retention of placenta in animal & $31(25.83)$ \\
\hline $\mathbf{3}$ & Infertility in animal & $24(20.00)$ \\
\hline $\mathbf{4}$ & Delay heat in animal & $22(18.33)$ \\
\hline $\mathbf{5}$ & Interrupted lactation & $48(40.00)$ \\
\hline $\mathbf{6}$ & Epididymitis and orchitis in the male animal & $13(10.83)$ \\
\hline $\mathbf{7}$ & Swelling of bursa of joint of limbs (Hygroma) & $19(15.83)$ \\
\hline $\mathbf{8}$ & Loose sexual desire and infertility in the bull & $11(9.17)$ \\
\hline
\end{tabular}

Table.5 Knowledge of dairy farmers about symptoms of human (suffering from brucellosis)

$(n=120)$

\begin{tabular}{|l|l|l|}
\hline Sr. No & Statements & No. (\%) of participants \\
\hline $\mathbf{1}$ & Infertility in human & $24(20.00)$ \\
\hline $\mathbf{2}$ & Undulant fever in human & $31(25.83)$ \\
\hline $\mathbf{3}$ & Insomnia in human & $21(17.50)$ \\
\hline $\mathbf{4}$ & Anorexia in human & $32(26.67)$ \\
\hline $\mathbf{5}$ & Headache in the human & $31(25.83)$ \\
\hline $\mathbf{6}$ & Arthralgia in human & $21(17.50)$ \\
\hline $\mathbf{7}$ & Constipation in human & $22(18.33)$ \\
\hline $\mathbf{8}$ & Sexual impotence in human & $17(14.16)$ \\
\hline $\mathbf{9}$ & $\begin{array}{l}\text { Depression in human } \\
\text { meningoencephalitis and endocarditis. }\end{array}$ & $19(15.83)$ \\
\hline $\mathbf{1 0}$ & $\begin{array}{l}\text { Brucellosis causes arthritis, spondylitis, sacroiliitis, osteomyelitis, } \\
\text { m }\end{array}$ & $2(1.67)$ \\
\hline
\end{tabular}


Table.6 Knowledge of dairy farmers about control of brucellosis diseases

\begin{tabular}{|l|l|l|}
\hline $\begin{array}{l}\text { Sr. } \\
\text { No }\end{array}$ & Statements & \multicolumn{1}{|c|}{$(\mathrm{n}=120)$} \\
\hline $\mathbf{1}$ & What did you do the carcass of a dead calve of infected animals? & $\begin{array}{l}\text { No. } \\
\text { participants }\end{array}$ \\
\hline $\mathbf{a .}$ & Buried or Burnt & $109(90.83)$ \\
\hline $\mathbf{b .}$ & Thrown outside village or farm & $11(9.17)$ \\
\hline $\mathbf{2}$ & $\begin{array}{l}\text { A veterinarian should be called for treatment of animals within } 24 \\
\text { hours of onset of symptoms }\end{array}$ & $105(87.50)$ \\
\hline $\mathbf{3}$ & $\begin{array}{l}\text { Brucellosis diseased person cannot be allowed to treat or handle } \\
\text { the animal }\end{array}$ & $59(49.17)$ \\
\hline $\mathbf{4}$ & $\begin{array}{l}\text { An injured person cannot be allowed to treat or handle the animal } \\
\text { without protection }\end{array}$ & $55(45.83)$ \\
\hline $\mathbf{5}$ & $\begin{array}{l}\text { Consumption of raw milk of infected animal can spread } \\
\text { brucellosis }\end{array}$ & $43(35.83)$ \\
\hline
\end{tabular}

Table.7 Knowledge of dairy farmers about preventive aspects of brucellosis diseases

$(\mathrm{n}=120)$

\begin{tabular}{|c|c|c|}
\hline $\begin{array}{l}\text { Sr. } \\
\text { No }\end{array}$ & Statements & $\begin{array}{l}\text { No. }(\%) \text { of } \\
\text { participants }\end{array}$ \\
\hline 1 & Brucella testing in animals is to be done twice a year & $6(5.00)$ \\
\hline 2 & $\begin{array}{l}\text { Brucellosis diseases can be prevented by using protective wears } \\
\text { (apron, gloves, gumboots, masks, etc.) }\end{array}$ & $63(52.50)$ \\
\hline 3 & Animal sheds should be regularly disinfected & $93(77.50)$ \\
\hline 4 & $\begin{array}{l}\text { Care should be taken while handling and disposing of foetus, } \\
\text { placental membrane and uterine discharge to prevent brucellosis }\end{array}$ & $78(65.00)$ \\
\hline 5 & $\begin{array}{l}\text { Proper boiling and pasteurization of milk \& its products can prevent } \\
\text { brucellosis diseases. }\end{array}$ & $68(56.67)$ \\
\hline 6 & $\begin{array}{l}\text { To avoid the consumption of uncooked/undercooked meat can } \\
\text { prevent brucellosis diseases. }\end{array}$ & $61(50.83)$ \\
\hline 7 & Brucellosis can be prevented in animals by vaccination & $36(30.00)$ \\
\hline 8 & Name the vaccine used for bovine brucellosis & $0(0.00)$ \\
\hline 9 & Age of animal ideally for Strain-19 Brucella vaccine & $4(3.33)$ \\
\hline 10 & Strain-19 vaccine can use to female calves. & $6(5.00)$ \\
\hline 11 & S-19 vaccine can use to male calves. (-) & $3(2.50)$ \\
\hline 12 & $\begin{array}{l}\text { Animal movements should be controlled to prevent spread of } \\
\text { brucellosis. }\end{array}$ & $22(18.33)$ \\
\hline 13 & Tick control can prevent spread of brucellosis diseases & $50(41.17)$ \\
\hline
\end{tabular}

*(-) indicates the negative question. 
Table.8 Knowledge level of different category of dairy farmers about brucellosis

\begin{tabular}{|c|c|c|c|c|c|c|c|}
\hline \multirow{3}{*}{$\begin{array}{l}\text { Sr. } \\
\text { No. }\end{array}$} & \multirow{3}{*}{$\begin{array}{l}\text { Knowledge } \\
\text { category }\end{array}$} & & & & & \multicolumn{2}{|c|}{$\mathrm{n}=120$} \\
\hline & & \begin{tabular}{|l} 
General \\
Disease \\
Information
\end{tabular} & $\begin{array}{l}\text { Trans } \\
\text { mission }\end{array}$ & $\begin{array}{l}\text { Symptoms } \\
\text { of animal }\end{array}$ & $\begin{array}{l}\text { Symptoms } \\
\text { of person }\end{array}$ & $\begin{array}{l}\text { Control } \\
\text { aspects }\end{array}$ & $\begin{array}{l}\text { Preventive } \\
\text { Aspects }\end{array}$ \\
\hline & & \multicolumn{6}{|c|}{ No. $(\%)$ of participants } \\
\hline 1 & $\begin{array}{l}\text { Low level (up to } \\
33.33 \% \text { ) }\end{array}$ & $\begin{array}{c}112 \\
(93.33)\end{array}$ & $\begin{array}{c}85 \\
(70.83)\end{array}$ & $\begin{array}{c}86 \\
(71.67)\end{array}$ & $\begin{array}{c}92 \\
(76.67)\end{array}$ & $\begin{array}{c}19 \\
(15.83)\end{array}$ & $\begin{array}{c}57 \\
(47.50)\end{array}$ \\
\hline 2 & $\begin{array}{l}\text { Medium level (33.34 } \\
\text { to } 66.66 \%)\end{array}$ & $\begin{array}{c}8 \\
(6.67)\end{array}$ & $\begin{array}{c}21 \\
(17.50)\end{array}$ & $\begin{array}{c}25 \\
(20.83)\end{array}$ & $\begin{array}{c}15 \\
(12.50)\end{array}$ & $\begin{array}{c}47 \\
(39.17)\end{array}$ & $\begin{array}{c}59 \\
(49.17)\end{array}$ \\
\hline 3 & $\begin{array}{l}\text { High level }(>66.66 \\
\%)\end{array}$ & - & $\begin{array}{c}14 \\
(11.67)\end{array}$ & $\begin{array}{c}9 \\
(7.50)\end{array}$ & $\begin{array}{c}13 \\
(10.83)\end{array}$ & $\begin{array}{c}54 \\
(45.00)\end{array}$ & $\begin{array}{c}4 \\
(3.33)\end{array}$ \\
\hline
\end{tabular}

Table.9 Knowledge level of dairy farmers in different major components about brucellosis

\begin{tabular}{|c|l|c|c|}
\hline Sr.No. & $\begin{array}{l}\text { Major components about } \\
\text { brucellosis }\end{array}$ & $\begin{array}{c}\text { Knowledge level of dairy } \\
\text { farmers in Percentage }\end{array}$ & Rank \\
\hline $\mathbf{1}$ & General information of brucellosis & 12.61 & 6 \\
\hline $\mathbf{2}$ & Transmission & 23.15 & 3 \\
\hline $\mathbf{3}$ & Symptoms of animal & 21.04 & 4 \\
\hline $\mathbf{4}$ & Symptoms of human & 18.33 & 5 \\
\hline $\mathbf{5}$ & Control & 67.64 & 1 \\
\hline $\mathbf{6}$ & Prevention & 31.41 & 2 \\
\hline
\end{tabular}

Table.10 Overall knowledge of dairy farmers about brucellosis diseases

\begin{tabular}{|l|l|l|}
\hline Sr.No. & Knowledge category & No. $(\%)$ of participants \\
\hline $\mathbf{1}$ & Low level (up to 33.33\%) & $90(75.00)$ \\
\hline $\mathbf{2}$ & Medium level $(33.34$ to $66.66 \%)$ & $27(22.50)$ \\
\hline $\mathbf{3}$ & High level $(>66.66 \%)$ & $3(2.50)$ \\
\hline
\end{tabular}

Table.11 Correlation ( $\mathrm{r}$ ) between the profile of the dairy farmers and knowledge of brucellosis

$(n=120)$

\begin{tabular}{|l|l|l|}
\hline Sr.No. & Variable & Pearson ' $r '$ ' value \\
\hline $\mathbf{1}$ & Age & $0.168^{\mathrm{NS}}$ \\
\hline $\mathbf{2}$ & Education & $0.076^{\mathrm{NS}}$ \\
\hline $\mathbf{3}$ & Experience in dairy farming & $0.253^{* *}$ \\
\hline $\mathbf{4}$ & Family type & $-0.101^{\mathrm{NS}}$ \\
\hline $\mathbf{5}$ & Family size & $-0.037^{\mathrm{NS}}$ \\
\hline $\mathbf{6}$ & Landholding & $0.122^{\mathrm{NS}}$ \\
\hline $\mathbf{7}$ & Livestock Herd Size & $0.225^{*}$ \\
\hline $\mathbf{8}$ & Social participation & $0.261^{* *}$ \\
\hline $\mathbf{9}$ & Extension participation & $0.471^{* *}$ \\
\hline $\mathbf{1 0}$ & Mass media exposure & $0.375^{* *}$ \\
\hline
\end{tabular}


Table.12 Adoption of dairy farmers regarding their practices associated to brucellosis infected animals

\begin{tabular}{|c|c|c|c|c|}
\hline \multirow{2}{*}{$\begin{array}{l}\text { Sr. } \\
\text { No. }\end{array}$} & \multirow{2}{*}{$\begin{array}{l}\text { Dairy farmers' practices when an animal } \\
\text { with bovine brucellosis is suspected or } \\
\text { detected }\end{array}$} & \multicolumn{3}{|c|}{ No. $(\%)$ of participants } \\
\hline & & $\begin{array}{c}\text { Most } \\
\text { farmers }\end{array}$ & $\begin{array}{c}\text { Some } \\
\text { farmers }\end{array}$ & No one \\
\hline 1. & Selling detected animal in the market & $\begin{array}{c}0 \\
(0.00)\end{array}$ & $\begin{array}{c}8 \\
(6.67)\end{array}$ & $\begin{array}{c}112(93.33 \\
)\end{array}$ \\
\hline 2. & Selling detected animal to neighbours & $\begin{array}{c}0 \\
(0.00)\end{array}$ & $\begin{array}{c}2 \\
(1.67)\end{array}$ & $\begin{array}{c}118(98.33 \\
)\end{array}$ \\
\hline 3. & Selling detected animal to relatives & $\begin{array}{c}0 \\
(0.00)\end{array}$ & $\begin{array}{c}4 \\
(3.33)\end{array}$ & $\begin{array}{c}116 \\
(96.67)\end{array}$ \\
\hline 4. & Giving medication to the detected animals & $\begin{array}{c}44 \\
(36.67)\end{array}$ & $\begin{array}{c}72 \\
(60.00)\end{array}$ & $\begin{array}{c}4 \\
(3.33)\end{array}$ \\
\hline 5. & Isolation of detected animal from others & $\begin{array}{c}29 \\
(24.17)\end{array}$ & $\begin{array}{c}66 \\
(55.00)\end{array}$ & $\begin{array}{c}25 \\
(20.83)\end{array}$ \\
\hline
\end{tabular}

Table.13 Adoption of dairy farmers regarding practices related to consumption of milk \& its products

\begin{tabular}{|c|c|c|c|c|}
\hline Sr.No. & Practices & Regularly & Sometimes & Never \\
\hline 1. & $\begin{array}{l}\text { Consume milk produced from your dairy } \\
\text { animals }\end{array}$ & $\begin{array}{c}54 \\
(45.00)\end{array}$ & $\begin{array}{c}31 \\
(25.83)\end{array}$ & $\begin{array}{c}35 \\
(29.17)\end{array}$ \\
\hline 2. & Purchase raw milk from other dairy farmers & $\begin{array}{c}0 \\
(0.00)\end{array}$ & $\begin{array}{c}7 \\
(5.83)\end{array}$ & $\begin{array}{c}113 \\
(94.17)\end{array}$ \\
\hline 3. & Boil raw milk before consumption & $\begin{array}{c}79 \\
(65.83)\end{array}$ & $\begin{array}{c}11 \\
(9.17)\end{array}$ & $\begin{array}{c}30 \\
(25.00)\end{array}$ \\
\hline 4. & $\begin{array}{l}\text { Boil raw milk before making milk products like } \\
\text { dahi, paneer etc }\end{array}$ & $\begin{array}{c}24 \\
(20.00)\end{array}$ & $\begin{array}{c}4 \\
(3.33) \\
\end{array}$ & $\begin{array}{c}92 \\
(76.67)\end{array}$ \\
\hline
\end{tabular}

It is observed in table 10 that majority of the dairy farmers $(75.00 \%)$ practicing dairy farming had low level of knowledge about brucellosis diseases followed by 22.50 and 2.50per cent of them were with medium and high level of knowledge of brucellosis, respectively.

The spearmen correlation analysis conducted to identify the relationship between factors affecting the knowledge level of dairy farmers about brucellosis and independent variables. An observation of table 11 shows that ' $r$ ' computed between factors of knowledge level of dairy farmers about brucellosis and experience in dairy farming (0.253), social participation $(0.261)$, extension participation (0.471) and mass media exposure $(0.375)$ were found to be significant at 0.01 level of significance. Livestock herd size $(0.225)$ was found to be significant at 0.05 level of significance. The remaining variable like age, education, family type, family size and land holding were observed to be no significant relationship.

Adoption of dairy farmers regarding their practices associated to brucellosis infected 
animals presented in table 12. Whenasked about how likely it is that dairy farmers sell detected brucellosis animals directly to neighbours or to relatives or in the market, the great majority of dairy farmers disagreed to sell susceptible or detected as brucellosis animals to neighbours $(98.33 \%)$ or relatives $(96.67 \%)$ or in the market $(93.33 \%)$.

Most of the respondents also felt that when they have animal suspected of having brucellosis, most dairy farmers would take measures such as treating the animal and isolation the animal from others.

Dairy farmers' opinion regarding practices related to consumption of milk \& its products presented in table 13reportedthat 45.00 per cent of respondents consumed milk regularly from their own animals. The majority of respondents $(65.83 \%)$ boiled milk regularly before it was consumed. In contrast, (Arif $e t$ al., 2017) reported that the majority (66\%) of the farmers' families were consumed raw milk and its products. On the other hand,76.67per cent reported that they never boiled milk before making milk product like dahi, paneer etc.

Level of knowledge of bovine brucellosis among dairy farmers $(75.00 \%)$ was low. Most of the farmers have no idea about causes the disease which may contribute to the spread of brucellosis.

There were more than half of dairy farmers had knowledge about buffalo (59.17\%) \& cow $(56.67 \%)$ can be susceptible to brucellosis but very less in other species like sheep \& Goat (25.83\%), Dog\& Cat (15.83\%) and Horse \& Camel (6.67\%). No one dairy farmer had any knowledge about a causative agent and vaccine name of brucellosis.

There was high majority of dairy farmers had low level of knowledge about general information of brucellosis disease, symptoms of human \& animals, transmission of disease and preventive aspect of disease.

The dairy farmers had high $(45.00 \%)$ and medium (39.17\%) level of knowledge on control aspects of brucellosis.

\section{Implication}

To provide training on zoonotic disease especially focus on brucellosis should be given to people working or contact direct or indirect with animals, milk, meat and product processing.

The public should be educated and informed about brucellosis diseases. To organize health campaign with frequent screening for brucellosis to identify infected animals so that it can be helpful to eradicate the disease.

The farmers are advised not to consume the raw milk and it must be boiled before consumption to prevent the brucellosis. Future research should be carried out on the prevalence of brucellosis in cow, buffalo, sheep, goat, dog and human beings.

\section{References}

Arif, S., Thomson P.C., Hernandez-Jover M, McGill D.M.,Warriach, H.M., Heller, J. (2017) Knowledge, attitudes and practices (KAP) relating to brucellosisin smallholder dairy farmers in two provinces in Pakistan. PLoS ONE 12(3): e0173365. https://doi.org/10.1371/journal.pone.01 73365

Diez, J.G., \& Coelho, A.C. (2013). An evaluation of cattle farmers' knowledge of bovine brucellosis in northeast Portugal. J. Infect. Public Health, 6, 363-369. http://dx.doi.org/10.1016/j.jiph.2013.0 
4.008

Hundal, J.S., Sodhi, S.S., Gupta, A., Singh, J., \&Chahal, U.S. (2016). Awareness, knowledge, and risks of zoonotic diseases among livestock farmers in Punjab. Vet. World., 9(2): 186-191.

Imadidden I. Musallam, Mahmoud N. AboShehada, and Javier Guitian. (2015). Knowledge, Attitudes, and Practices Associated with Brucellosis in Livestock Owners in Jordan. Am. J. Trop. Med. Hyg., 93(6), 1148-1155 http://dx.doi.org/10.4269/ajtmh.15-
0294

Seleem, M.N., Boyle, S.M. \& Sriranganathan, N., 2010, 'Brucellosis: A re-emerging zoonosis', Veterinary microbiology 140 , 392-398. http://dx.doi.org/10.1016/j. vetmic.2009.06.021, PMid:19604656

Thakkar, A.P. (2013). Study on knowledge of dairy farmers of Anand district about zoonotic diseases. Unpublished master's thesis, Anand Agricultural University, Anand, India.

\section{How to cite this article:}

Jadav S. J. and Raval S. K. 2019. Consciousness of Dairy Farmers about Brucellosis. Int.J.Curr.Microbiol.App.Sci. 8(09): 1404-1415. doi: https://doi.org/10.20546/ijcmas.2019.809.161 